\title{
Comment on Manchikanti et al's ACOEM Guideline Criticism
}

\section{TO THE EDITOR:}

As practicing interventional pain physicians, we were pleased to see the point-by-point evaluation of the recent ACOEM guidelines (1,2). Although the 400page ACOEM chapters at first glance appear impressive, through this analysis it becomes clear that the ACOEM chapters are fatally flawed. Unfortunately, insurance companies have been quick to accept any information that allows them to deny payment.

Manchikanti et al (1-3) have illustrated clearly that these guidelines fail to incorporate much of the medical literature including the best available evidence in support of these therapies. Manchikanti et al have done a thorough, scholarly, and rigorous evaluation of the ACOEM guidelines, and provided the pain community with a solid basis for rebutting insurance denials.

At any rate, we fear that universal adoption of these flawed guidelines will impair patients' access to interventional pain medicine therapies within and outside the worker's compensation arena. This would be an injustice to the entire pain patient population.

\author{
Lora L. Brown, MD \\ Coastal Pain Management and Rehabilitation \\ 6015 Pointe West Boulevard \\ Bradenton, FL 34209 \\ painmedicinedoctor@hotmail.com \\ Luis A. Escobar, MD \\ 601 N. Flamingo Road \\ Suite 101 \\ Pembroke Pines, FL 33028 \\ Alvin Stein, MD \\ 4101 NW 4th Street \\ Suite 401 \\ Plantation, FL 33317 \\ www.proloshot.com
}

\section{References}

1. Manchikanti L, Singh V, Derby R, Helm $S$, Trescot AM, Staats PS, Prager JP, Hirsch JA. Review of occupational medicine practice guidelines for interventional pain management and potential implications. Pain Physician 2008; 11:271-289.
Manchikanti L, Singh V, Helm S, Trescot AM, Hirsch JA. A critical appraisal of 2007 American College of Occupational and Environmental Medicine (ACOEM) practice guidelines for interventional pain management: An independent review utilizing AGREE, AMA, IOM, and other criteria. Pain Physician 2008; 11:291-310.
3. Manchikanti L, Singh V, Derby R, Schultz DM, Benyamin RM, Prager JP, Hirsch JA. Reassessment of evidence synthesis of occupational medicine practice guidelines for interventional pain management. Pain Physician 2008; 11:393482. 